\title{
MEF2C wt Allele
}

National Cancer Institute

\section{Source}

National Cancer Institute. MEF2C wt Allele. NCI Thesaurus. Code C92162.

Human MEF2C wild-type allele is located in the vicinity of $5 q 14$ and is approximately 186 $\mathrm{kb}$ in length. This allele, which encodes myocyte-specific enhancer factor $2 \mathrm{C}$ protein, is involved in the mediation of cardiac morphogenesis, muscle cell differentiation and vasculogenesis. Mutations and deletions of the gene are associated with severe mental retardation, stereotypic movements, epilepsy, and cerebral malformation. 